\title{
Effectiveness of authentic performance tasks: The case of a special education course
}

\author{
Ufuk Uluçınar ${ }^{1}$ and Erkan Dinç² \\ ${ }^{1}$ Uşak University, Faculty of Education, Turkey (ORCID: 0000-0001-9167-5457) \\ ${ }_{2}^{2}$ Anadolu University, Faculty of Education, Turkey (ORCID: 0000-0002-0953-3351)
}

\begin{abstract}
Designed as participatory action research, this study aims to develop authentic tasks as assessment and evaluation activities in an undergraduate special education course, and to examine the impact of these tasks on students' experiences, viewpoints and feelings during the implementation processes. The study group was comprised of 205 student teachers collaboratively working in groups. The participants prepared forty separate mini research projects in relation to special education and students with special needs. Research data was collected through collective research diaries, in which the participants reflected their experiences, thoughts and feelings in relation to the performance tasks they took part in. A qualitative content analysis was carried out to examine the available data, which was accompanied by constant comparative analysis procedures to ensure the reliability of the analysis processes. The research findings show that authentic performance tasks improve student teachers' professional development, help them to enhance their repertoire on research, methodology and science process skills, and develop their skills of self-confidence, self-efficacy, communication, interaction and the use of technology. The results indicate that the performance tasks are fun, innovative, motivating and educative for the participants. Therefore, they have living experiences contributing to them from various aspects.
\end{abstract}

Keywords: Understanding by design; Authentic learning; Assessment and evaluation; Special education; Student teachers

Article History: Submitted 23 February 2021; Revised 28 May 2021; Published online 27 June 2021

\section{Introduction}

In certain disciplines, students have been asked to memorize certain formulas and basic concepts. However, why they need to know these formulas and how to use them to solve real life problems are rarely addressed. As Bhagat and Huang (2018) assert, the memorized knowledge/information does not last long in learners' minds, because it is not related or connected to their real lives. Similarly, undergraduate students are expected to perform mostly abstract performances and activities that are not contextualized or connected to any real-life situation (Lebow \& Wager, 1994) since several undergraduate courses encourage individual effort and cognitive achievement rather than collaborative learning experiences. Most learning-teaching activities are largely individual, with little opportunity for students to collaborate and think (Herrington \& Herrington, 2006). To encourage students to think and reflect connections between what they learn in school and their

Address of Corresponding Author

Ufuk Uluçınar, PhD, Division of Curriculum and Instruction, Uşak University, 1 Eylül Campus, 64000, Uşak, Turkey.

$\triangle$ ufuk.ulucinar@gmail.com

How to cite: Uluçınar, U. \& Dinç, E. (2021). Effectiveness of authentic performance tasks: The case of a special education course. Journal of Pedagogical Research, 5(2), 152-171. http:/ / dx.doi.org/10.33902/JPR.2021270069 
lives outside of school should be made. To do this, authentic learning experiences can be provided to enable students to learn new information in their original contexts using of discussion, examination, and the production of authentic materials and stories collaboratively (Bhagat \& Huang, 2018).

In authentic project studies, students can go beyond understanding information and begin to think critically on the facts they have learned (Laiken, 2006; Laur, 2013). To realize this and to improve education, the relevant curricula must support learners' high-level cognitive development by helping them deal with authentic problems (Pierrakos et al., 2010). It has been observed that the learning experiences that undergraduate students remember the most include certain tasks, such as examining daily life or researching local history. This means that students need to be engaged in authentic and realistic learning tasks involving complex collaborative activities To attain authentic learning experiences. The authentic approach requires more effort than standard academic teaching methods, such as direct instruction and discussions (Herrington et al., 2010). Dennis et al. (2013) also draw attention to the role and potential benefits of authentic assessment in the classroom compared to traditional assessment methods. Relevant literature includes the following: authentic learning experiences; the formation of professional identities in teachers' professional lives (Haston \& Russell, 2012); perceptions of self-efficacy (Dewer \& Clement, 2016); knowledge and skills related to course design (Lowell \& Moore, 2020); cognitive and metacognitive skills (Mohammedi, 2017); achievement, attitude and individual learning skills (Hursen, 2016); literacy skills (Önger \& Çetin, 2018); motivational beliefs for technology integration; self-efficacy perceptions and intrinsic goal orientation (Banas \& York, 2014a; Banas \& York, 2014b; Banas, 2014); and self-confidence and abilities (Russell-Bowie, 2012).

\subsection{Understanding by Design and Authentic Performance Tasks}

Backward design or Understanding by Design is a systematic, planned curriculum design model developed by Wiggins and McTighe (1998). The theory of this model encapsulates the assumption that 'students understand knowledge and skills, and then apply what they understand in a different context'. This model consists of three basic components; defining the desired outcomes, determining the evaluation evidence, and planning the teaching. The determination of the performance tasks and evidence by which the students transfer what they have learned takes place before the planning of the instruction. Performance tasks are designed in line with certain principles and standards by fulfilling a performance that is suitable for a specific role and a target audience (Wiggins \& McTighe, 2011, 2012). The performance tasks in the current study are designed in accordance with the understanding of design model, but the planning phase of the instruction has been left out.

\subsection{Special Education Lesson and Authentic Learning Experiences in Teacher Education}

The training of students with special educational needs [SEN] comprises inclusive education along with special education courses designed and implemented for various SEN student groups. The data was provided by the Turkish Ministry of National Education for 2019-2020. There was a total of 425,774 students with various types of disabilities/special needs who continued formal education from kindergarten to secondary education (Ministry of National Education [MoNE], 2020). This indicates the importance of training special education teachers, as well as helping student teachers in various subject areas to equip them with relevant knowledge/information and skills related to special education and students with SEN, and to practice these skills in authentic contexts.

In fact, all teacher education programs in Turkish teacher training institutions include a 'special education' course. However, similar to most other taught courses, the practice of this 'special education course' is mostly based on the transfer of theoretical content knowledge in most teacher training institutions, without including any practical or authentic tasks (Bozgeyikli, 2018; Aksoy et al., 2018). The current study aims to enable student teachers to gain authentic learning experiences beyond the acquisition of theoretical knowledge regarding special education. It was thought that 
providing opportunities for student teachers to communicate and interact with individuals with SEN or their relatives would enable them to develop related knowledge, skills and orientation (McCall et al., 2014).

It can be seen that many studies, focusing on the training of student teachers to gain awareness and expertise relating to individuals with SEN, have addressed the role and effects of authentic learning experiences. For example, Bruffy (2012) reveals the effect of authentic tasks on the academic performance and social interaction of ordinary students and those with SEN. There have been many studies investigating the effects of authentic learning tasks and/or environments on the training of teachers to teach individuals with SEN. A study using place-based learning as an authentic learning method used to establish educational and social connections between student teachers and children with SEN, provided that there has been an increase in trainee teachers' awareness of those with SEN and in their sense of social responsibility (Best et al., 2017). Zagrodnik et al. (2017) designed a community-based in-service learning program called CAPES, aiming to improve the experience and social participation skills of individuals with SEN, their family members and student teachers involved in the study. In this program, the aim is to support the development of physical, social, emotional and behavioral skills of students with various facilities. Communication and interaction between those with SEN, their family members and student teachers provide the chance for student teachers to authentically practice the theoretical knowledge they had learnt in special education classes. It was found that their involvement in the given processes had a positive impact on the development of student teachers' beliefs and attitudes in relation to individuals with SEN and their involvement in learning processes. A study by Koçyiğit and Zembat (2013) also reveals that authentic tasks related to SEN provided for student teachers of pre-school education have a direct impact on their problem-solving skills and attitudes towards special education.

It has been noted in the relevant literature that authentic learning experiences influence student teachers' knowledge, skills and attitudes in relation to individuals with SEN. On the other hand, it has been claimed that the current study has a potential to provide student teachers with an authentic, rich and quality learning experience regarding special education. Within the given context, the current study aims to assess the effectiveness of the authentic performance task developed and practised within an undergraduate special education course.

\section{Method}

Designed as participatory action research, the aim of this study is threefold as suggested by Carr and Kemmis (2002). The first is to improve the context of teacher education in relation to the areas of special education and inclusive education. The second is to develop student teachers' understanding of special education, inclusive education, SEN, individuals with SEN and their families. The third is to improve and enrich the design and content of the special education course taught in teacher education programs. The purpose of student teachers' participation in these tasks is to enable them take responsibility for improvement (Carr \& Kemmis, 2002) as well as to a gain meaningful learning experience.

The current study provides eleven mini authentic performance projects or tasks: interviewing individuals with SEN, their families and their teachers; observing individuals with SEN; designing blogs; designing campaigns; debating and performing dramas; conducting film analyses and street interviews; and photographing spaces designed for ordinary people and for those of the handicapped. These performance tasks covering twelve disability areas, such as mental retardation and autism spectrum disorder, are carried out as collaborative group work. Each group, formed from four or five student teachers, has a unique learning experience in relation with a disability area by means of these authentic performance tasks.

Authentic performance tasks included in the current study are designed in accordance with the Understanding by Design Model developed by Wiggins \& McTighe (1998; 2011; 2012). These tasks are regarded as the assessment and evaluation components of the special education course, which 
the participating student teachers enrolled in. On the one hand, the researchers designed the overall framework of the research and authentic performance tasks, distributed the tasks amongst the groups of student teachers, decided on the roles and responsibilities of each group and every participant within the course of the research, monitored all phases and stages of the study. They also helped the participants whenever they were in need, and finally responded to their queries/questions if there were any. On the other hand, working in groups, the participating student teachers customized, prepared, refined and practised the authentic performance task assigned to them, and kept collective research diaries. Within this context, the current study is the outcome of a collective and collaborative practice carried out by the researchers and the participating student teachers. It has developed an authentic, dynamic, circular, reflective and continuous research framework, including systematic, purposeful and practical work actively carried out by the participants, as pointed out by Alexakos (2015).

\subsection{Process}

The research process consists of five items or phases: planning the design of the action; management of the design and distribution of the tasks; preparation of the authentic performance tasks; the implementation process; and finally, the presentation of the outcomes and evaluation.

\subsubsection{Planning the design of the action}

A total of eleven different authentic performance tasks were envisaged for the participating student teachers. Next, the goals of these performances and the stages to be followed were designed. Below is an example of the purpose and processes of a performance task.

Table 1

Example of 'instructions for a performance task'

Research-based Task descriptions

performance tasks

1. Designing a Goal. The members of this group are expected to design a campaign to make the campaign voices of the people with SEN living in difficult conditions heard and to solve their problems.

Tasks:

To achieve the above goal, the following steps should be followed.

1. Reading the section related to this topic.

2. Getting to know the various campaign tools that could be accessed at this link:

(http://panel.stgm.org.tr/vera/app/var/files/k/a/kampanyakitapweb.pdf).

3. Keeping the topic in mind, deciding on the campaign tools.

4. Designing a suitable campaign text and creating the selected campaign tool, using the examples of the campaign texts in the link above.

5. To present the designed campaign tool in the classroom.

\subsubsection{Management of design and distribution of performances}

The topics to be studied and the authentic performance tasks were randomly distributed amongst the groups of student teachers by a two-phase drawing of lots; one for choosing the topics and the other for selecting the type of task. As a result, each group was able to design, prepare and implement different performance tasks on different topics. At the end of this process, the groups of student teachers, studying in five different subject areas and taking the special education course were assigned to perform the tasks presented in Table 2 .

A virtual classroom was created in the Google Classroom App for each class. After the distribution of the study topics and tasks, all of the student teachers were invited to download the Google Classroom application and then sign up for their respective classes. After this, the details of 
each group's topic and performance task were assigned as group work and made visible only for the members of the relevant group. The screenshots of the virtual classroom in the Google Classroom App explaining this process are presented in Figure 1 and Figure 2.

Figure 1

A screenshot of instructions for the performance tasks in Google Classroom

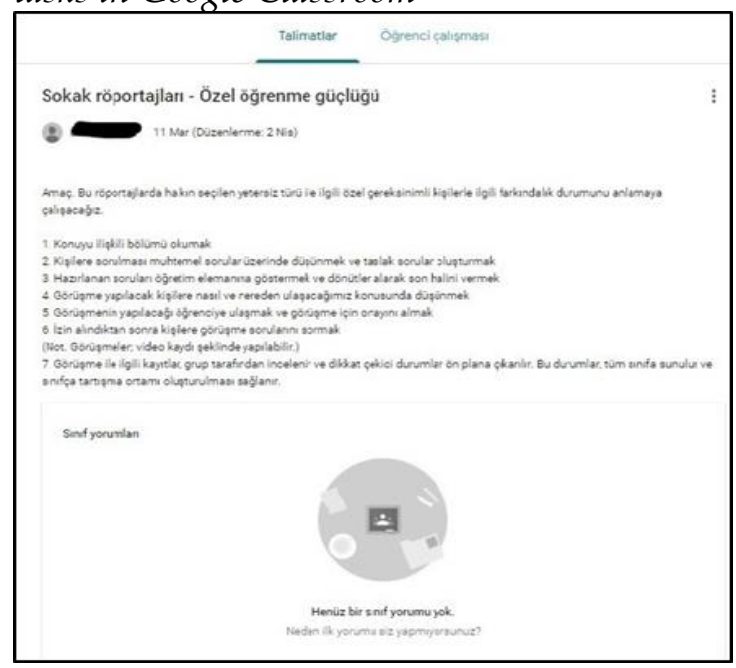

Figure 2

A screenshot of group works in the Google Classroom

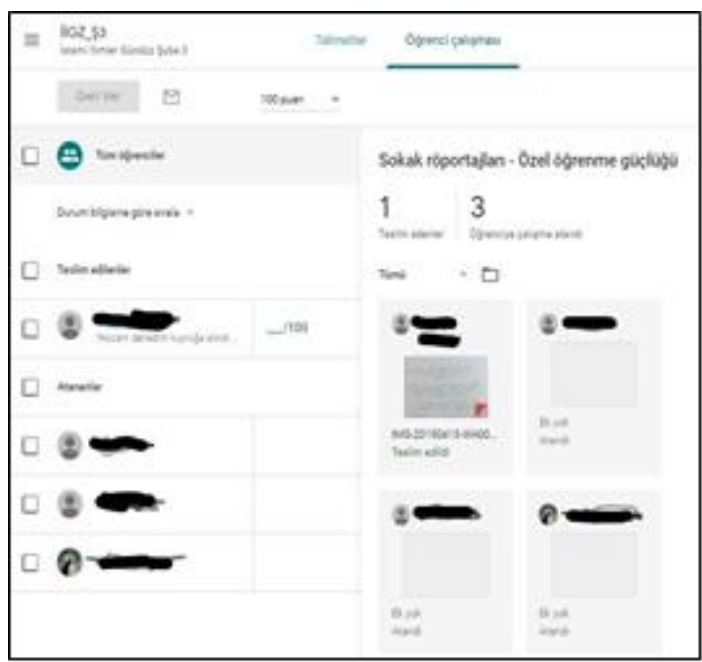

\subsubsection{Preparation of the authentic performance tasks}

Each group made their preparations to perform their given tasks and presented them to the researchers for reviewing and feedback using the virtual classroom. After the feedback provided by the researchers, each group revised their planning and its content to finalize their prospective tasks. For example, one of the groups, which was assigned to conduct street interviews with lay persons on issues related to SEN and individuals with SEN, first prepared a draft interview schedule.

After reviewing the draft interview schedule, the instructor/researcher provided the following response: "We will try to understand the public awareness of children with special learning difficulties as our task in street interviewing. Let's go over the questions again and try to make them as clear as possible, ordering them in a sequence, starting from more general ones to arriving at specific ones." After this feedback, the relevant group revised the second version of their interview schedule.

Review of the above questions and feedback was provided by the researchers. The relevant group of participating student teachers revised their interview schedule and then produced the final version of it presented.

This group conducted street interviews with volunteers, using this final interview schedule in Appendix 1.

\subsubsection{Implementation process}

The participating student teachers put their performance plans into practice at this stage. In the example given above, the relevant group conducted their street interviews.

\subsubsection{Presentation of the outcomes and evaluation}

At this stage, each group of participants presented the outcomes of their performance tasks in their classes. The presentations were prepared in accordance with the performance task each group carried out using the appropriate type of sources or materials produced within the course of their mini projects. Next, the members of the relevant group reflected on their experiences in relation to the performance tasks. This was followed by comments and evaluations offered by other classmates and the researchers. 


\subsection{The Study Group}

The study group is comprised of 205 student teachers enrolled in a special education course in five different branches of the Faculty of Islamic Sciences at a public university. As Table 2 reveals, each containing four or five student teachers of forty-eight separate groups formed.

\subsection{Data}

\subsubsection{Research diary}

Each group was invited to write a collective diary containing their experiences, thoughts, feelings and problems encountered while carrying out these authentic performance tasks, along with the contributions the involvement in all these processes provided them. They were also asked to express their opinions on using Google Classroom in this process as a virtual learning environment.

\subsection{Data analysis}

Qualitative content analysis was conducted to analyze the data extracted from the collective research diaries written by the participants. Data analysis projects were generated in DEDOOSE, that is qualitative data analysis software, for collective research diaries written in the context of each performance (e.g. campaign design). Totally, 11 projects (for 11 performance tasks) were conducted on the software. Participants' statements in each performance were firstly coded, and then the codes generated were transformed to categories and themes as shown in Table 3. - 9. The processes of coding, categorization and theme generation were implemented inductively. For example, categories of authentic learning, planning / decision making, observing, inquiring, problem solving, and interpreting were transformed to a theme "research and science process skills" as more abstract concept as indicated in Table 3. After that, 15 separate themes were combined to one axial theme and six inclusive themes which is wider and comprehensive than 15 themes as seen in Figure 3. In order to ensure the credibility of the data analysis, code-code comparison, code-raw data comparison, and raw data-raw data comparison were conducted both within each performance task and between performance tasks. After this, it was attempted to reveal similar or divergent aspects of the findings accurately and completely.

\subsection{Credibility and Transferability of the Research}

\subsubsection{Intensive and rich description}

Each process performed in the study is explained in detail. At least one piece of evidence or proof was provided for each process. For example, a sample of instructions for student teachers to follow while implementing a performance task, the draft interview schedule they prepared, the feedback statements provided by the researchers, and the finalized version of the interview schedule were presented as evidence supporting the credibility of the research processes. In addition, screenshots from the Google Classroom platform were also utilized for the same purpose. In order to provide clarity and transparency at every step of the research process, ranging from design to implementation, everything encountered was intensively described.

\subsubsection{Method triangulation}

Possessing an authentic design dimension, each of the performance tasks carried out within this research was also regarded as a research method as well as an activity. The findings obtained through each method or task are presented in a table, and then interpreted. These methods also assisted the researchers in finding the divergent and convergent findings. Taking active roles and responsibilities in the research processes helped student teachers to gain new knowledge, skills and understanding of individuals with SEN. Therefore, it was observed that a diversification, made in terms of methods or performance tasks, contributed to the internal validity of the study. 


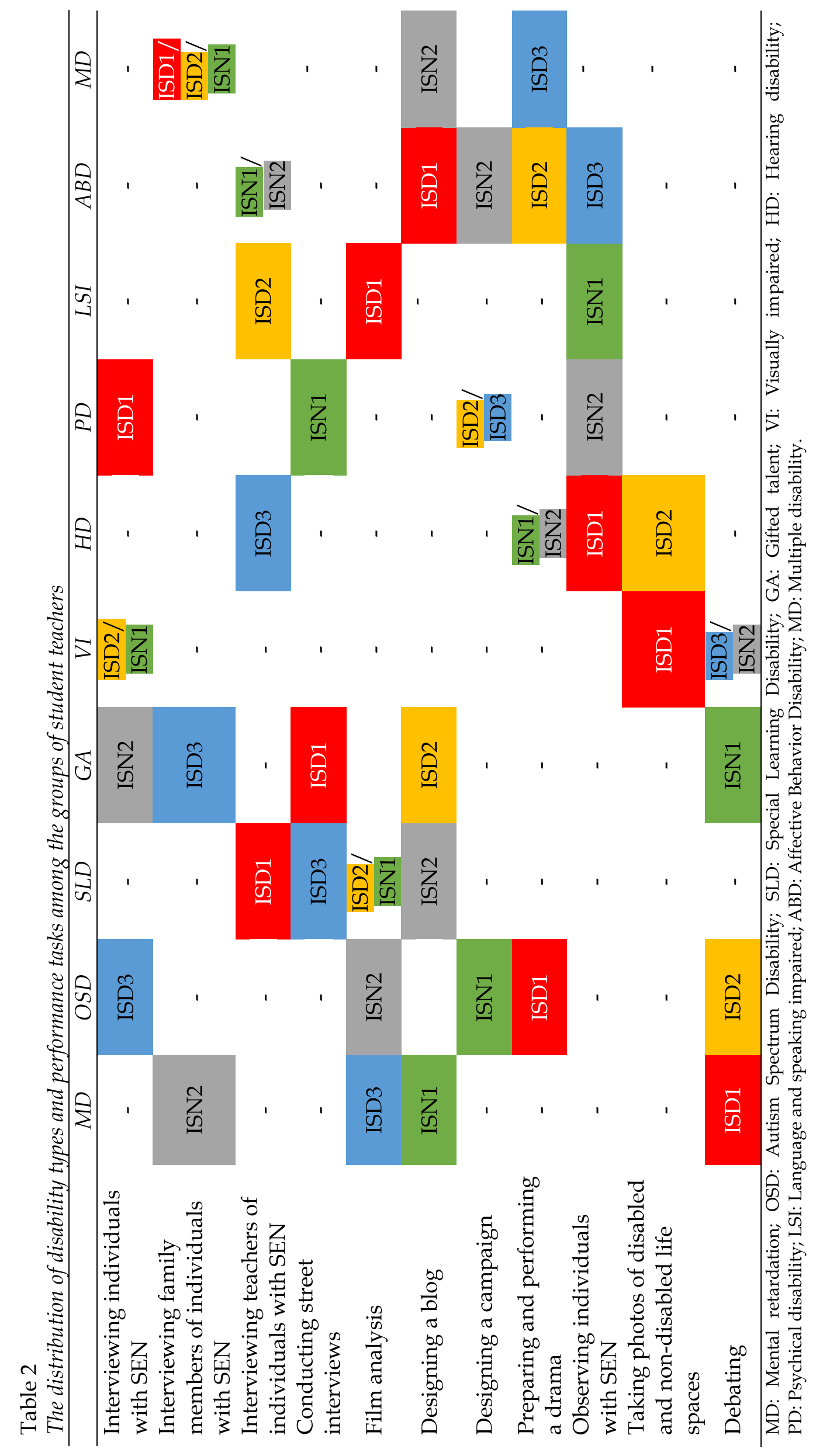




\section{Results}

Stemming from analytical processing, this section summarizes student teachers' experiences, feelings, thoughts and other relevant issues in the processes of designing, implementing and sharing authentic performance tasks in an undergraduate special education course. The analysis ends with producing six inclusive themes obtained through re-associating seventeen themes hierarchically. The causal relationships between these inclusive themes and the axis theme are presented in Figure 3.

Figure 3

The structure of and the interaction between themes and inclusive theme

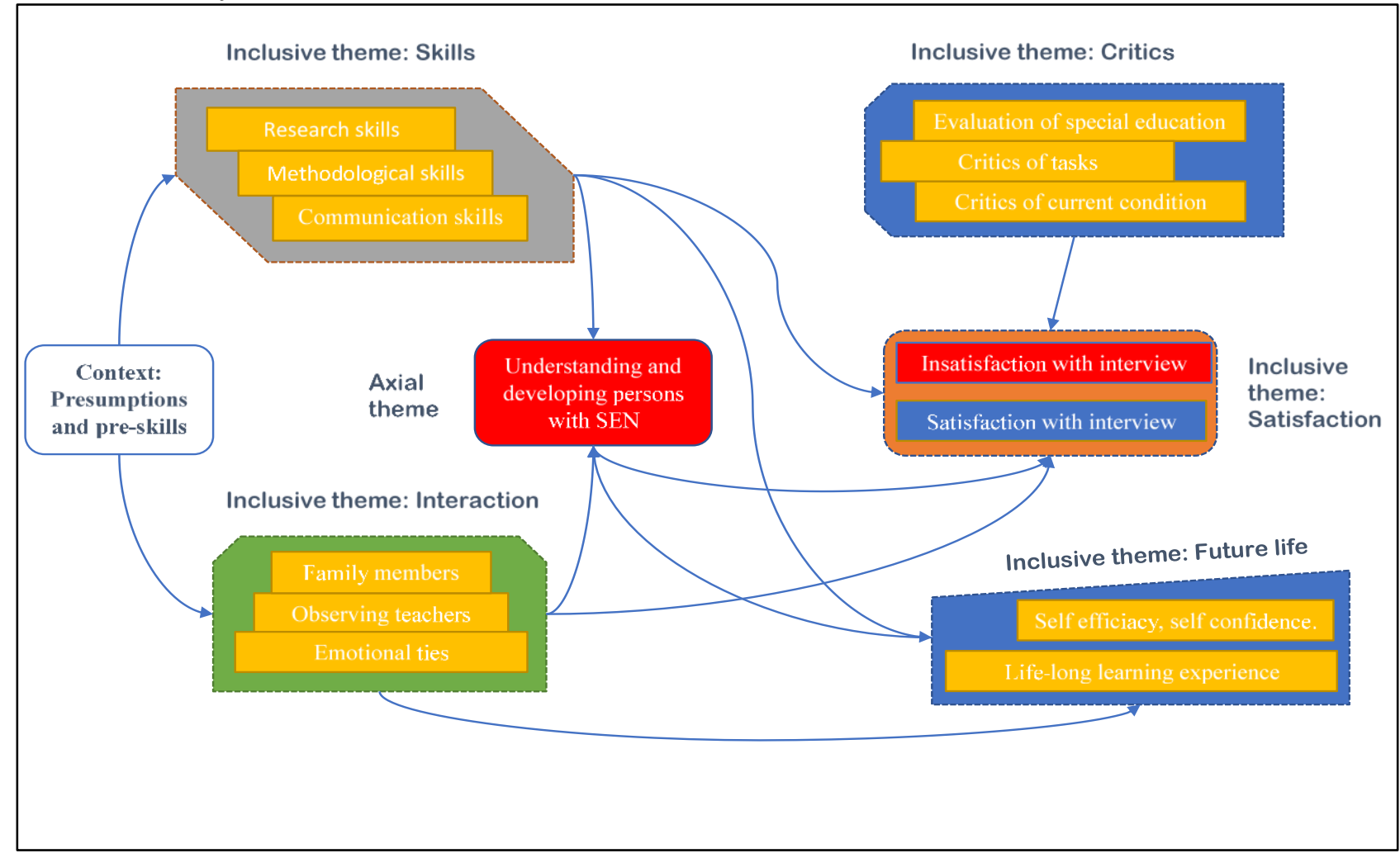

After the processes of coding and re-coding, six inclusive themes shaped around an axis theme (understanding towards individuals with SEN) were discovered. The first inclusive theme is the insufficient or incomplete prior knowledge and skills of student teachers before their performance tasks. As a result of conducting interviews with individuals with SEN and their family members and teachers, they had opportunities to interact with these people, learn about them and broaden their perspectives. The development of scientific, methodological, communicative, visualization and manual skills were included in the inclusive theme of skill. Interacting with individuals with SEN and acquiring the above given skills reinforced the development of understanding towards individuals with SEN, which emerged as the axis theme. Another inclusive theme, satisfaction, also arose through the interaction and skills mentioned above. In addition, all these developments and experiences prepared the ground for shaping another inclusive theme; future life. The last inclusive theme called criticism includes the inadequacy of conditions for special education, criticism of relevant research studies and criticism of the performance task carried out as part the current study.

At this stage, the findings are reduced to more specific themes and categories indicating the convergences and divergences in the findings observed among performance tasks. Symbols specific to each performance are shown in the matrix. Table 3 illustrates categories and themes that were discovered under the inclusive theme of skills.

Table 3 summarizes the categories and themes under the skills inclusive theme. 
Table 3

Categories and themes observed under the inclusive theme of 'Skills'

\begin{tabular}{|c|c|c|c|c|c|c|c|c|c|c|c|c|}
\hline Themes & Categories & IFM & IIS & $B D$ & $P D$ & $F A$ & $P S D$ & OfI & $C D$ & $D$ & IT & SI \\
\hline \multirow{4}{*}{$\begin{array}{l}\text { Context: Pre- } \\
\text { suppositions and } \\
\text { pre-skills }\end{array}$} & $\begin{array}{l}\text { Being a novice } \\
\text { researcher }\end{array}$ & $\diamond$ & $\Delta$ & $\square$ & $\cdot$ & $\circ$ & & $\square$ & $\square$ & e & $\omega$ & 0 \\
\hline & $\begin{array}{l}\text { Fear of } \\
\text { communication }\end{array}$ & $\diamond$ & $\Delta$ & & & & & $\square$ & & & $\omega$ & \\
\hline & $\begin{array}{l}\text { Having biased } \\
\text { attitudes }\end{array}$ & & & $\square$ & $\cdot$ & & & & & & & \\
\hline & Inappropriate tasks & & & & - & & & & & & & \\
\hline \multirow{6}{*}{$\begin{array}{l}\text { Research and } \\
\text { science process } \\
\text { skills }\end{array}$} & Authentic learning & $\diamond$ & $\Delta$ & & & & & $\square$ & & & $\omega$ & \\
\hline & $\begin{array}{l}\text { Planning/ decision } \\
\text { making }\end{array}$ & $\diamond$ & $\Delta$ & & & & & & & & & \\
\hline & Observing & $\diamond$ & $\Delta$ & & & o & $\mathfrak{e}$ & $\square$ & $\square$ & & $\omega$ & \\
\hline & Inquiring & & $\Delta$ & $\square$ & & & $\mathfrak{e}$ & & & & $\omega$ & \\
\hline & Problem solving & & $\Delta$ & & & & & & & & & \\
\hline & Interpreting & & & & & & $\mathfrak{e}$ & & & & & \\
\hline \multirow{5}{*}{$\begin{array}{l}\text { Methodological } \\
\text { knowledge and } \\
\text { skills }\end{array}$} & $\begin{array}{l}\text { Studying } \\
\text { cooperatively }\end{array}$ & $\diamond$ & $\Delta$ & $\square$ & $\cdot$ & o & & & $\square$ & e & & 0 \\
\hline & $\begin{array}{l}\text { Conducting } \\
\text { interview }\end{array}$ & $\diamond$ & $\Delta$ & & & & & & & & $\omega$ & \\
\hline & Designing blogs & & & $\square$ & & & & & & & & \\
\hline & Performing drama & & & & - & & & & & & & \\
\hline & $\begin{array}{l}\text { Leaning sign } \\
\text { language }\end{array}$ & & & & $\cdot$ & & & $\square$ & & & & \\
\hline \multirow{3}{*}{$\begin{array}{l}\text { Effective } \\
\text { communication } \\
\text { skills and self } \\
\text { confidence }\end{array}$} & $\begin{array}{l}\text { Self-expression } \\
\text { skills }\end{array}$ & & & & & & & & & o & & \\
\hline & $\begin{array}{l}\text { Defending } \\
\text { ideas/viewpoints }\end{array}$ & & & & & & & & & o & & \\
\hline & Readiness to debate & & & & & & & & & e & & \\
\hline
\end{tabular}

Abbreviations for Performance Tasks: IFM: Interviewing family members; IIS: Interviewing individuals with SEN; BD: Blog design; PD: Performing drama; FA: Film analysis; PSD: Photographing living spaces with disabilities, OfI: Observation; DC: Designing a campaign; D: Debating; IT: Interviewing teachers; SI: Street interviews.

Context: Pre-suppositions and pre-skills. Being a novice in research, fear of communication, having prejudice and biased attitudes about the task and procedures, and the performance task not being suitable for one's abilities and capacities are issues raised by the participants. These issues are categorized under the title of pre-suppositions and pre-skills. It can be seen that the participants have difficulties in performing most of the tasks, apart from photographing living spaces shared with disabled persons. One participant initially stated his fear of inexperience and hesitation about the drama activity saying,

"...his research gave us courage. At the beginning we thought that we would never perform a drama, but we realized that it was not that difficult later on. Being able to do new and challenging things raised our courage. This also enabled us to understand people with hearing impairment."

One of the things felt before the performance tasks was the fear of communication. Another student teacher, who took part in conducting interviews with those with SEN, expressed disquiet in the following words:

"I have always been curious about the feelings and thoughts of people with disabilities, but thinking that I would hurt them, I couldn't dare to ask. Taking part in this experience encouraged me to put myself in their shoes and understand their thoughts."

These extracts provide evidence as to what the participants acquired within the processes of the current study. 
Research and science process skills. One important acquisition gained by the participating student teachers is research/science process skills. They had the opportunity to learn authentically by actively being involved in the processes of decision-making, problem-solving, observation, interaction, planning and the conducting of inquiries, the collection of data, analysis of data and the interpretation of the findings. For example, a number of the participants who took part in conducting interviews with those with SEN, their family members and their teachers had the chance to practice the skills of drafting interview questions and revising and arranging them in accordance with the given feedback and interaction with these people in real life situations. In addition, it was observed that there was improvement in the participants' observation and interaction skills, provoking them to reflect on what they had been trying to do. One of the student teachers participating in the interviewing of individuals with SEN expressed this fact saying, "I started to feel the need to observe more people around me, and realized that I could do things which I couldn't imagine doing previously." During these performance tasks, student teachers had the opportunity to conduct inquiries. Moreover, the participants also learned to solve problems, take photos of various living spaces and interpret them.

"I did not have much difficulty in finding places to take photos, after I realized that there were so many obstacles before disabled people. I also realized that we could not see the difficulties unless we really wanted to see..."

The above reflections on what she had observed during her task indicate the awareness gained by one of the participants.

Methodological knowledge and skills. It was found that a number of the participants acquired methodological knowledge and skills related to working cooperatively in groups, preparing and conducting interviews, designing blogs, performing dramas and learning sign language. A student teacher participating in the drama activity stated that:

“Our task was to attract people's attention to hearing impairment through performing a drama. We tried to sing a song in sign language. I don't know how successful we were in doing that. However, I realized that after getting this task I started to look at individuals with hearing impairment differently, and paying attention to sign language as well. Now, I am thinking of learning sign language when I have an opportunity to do so. It is good to realize that they are not different from us."

This extract reveals that taking parts in the performance tasks not only enabled the participants to acquire methodological knowledge and skills, but also provoked their awareness of and sensitivity towards persons with SEN.

Effective communication and self-confidence. Another research finding indicates student teachers' development in expressing themselves, defending their ideas and taking part in debates.

"Our topic of discussion was, 'Should children with Down Syndrome be aborted before birth or not?' While I was arguing against abortion, I tried to predict my opponent's claims. It was the first time I had an opportunity to defend an idea or a case against someone else."

The above statement can be regarded as proof that carrying out performances improved the participants' thinking and reflection skills as well as their communication skills.

Table 4 summarizes the categories and themes under the skills future life inclusive theme.

Self-efficacy, self-confidence, perspective development. Another emerging theme is the observed changes in self-efficacy, self-confidence and perspective development of the participants. As one of the participants who took part in the campaign design states,

"The positive aspect of this assignment for me is that I realized I could do things that I had not experienced before. I could never have imagined that I could do homework with Google Paint, which I played with when I was younger".

Things they have done during the performance tasks allowed them to have unique experiences. In addition, certain performances also broadened participants' perspectives and increased their enthusiasm for learning, while other tasks like designing blogs, observation and debating 
improved their self-efficacy skills. Another participant's statement indicates how the authentic performance tasks improved their perspectives of others, especially persons with SEN: "This performance was the cause of gratitude for me and I should thank God. I realized the value of my good health and I started to pray for the continuity of my mental and physical health". The findings also reveal that the activities they were involved in assisted the participants to develop the skills of imagination and empathy.

Table 4

Categories and themes observed under inclusive theme 'Future life'

\begin{tabular}{|c|c|c|c|c|c|c|c|c|c|c|c|c|}
\hline Themes & Categories & IFM & IIS & $B D$ & $P D$ & $F A$ & $P S D$ & OfI & $C D$ & $D$ & $I T$ & $S I$ \\
\hline \multirow{7}{*}{$\begin{array}{l}\text { Self-efficacy, } \\
\text { self-confidence, } \\
\text { perspective }\end{array}$} & Being self-efficient & $\diamond$ & & & $\cdot$ & o & & & $\square$ & ळ & $\mathrm{GO}$ & o \\
\hline & $\begin{array}{l}\text { Being enthusiastic } \\
\text { to learn }\end{array}$ & $\diamond$ & & & $\cdot$ & $\circ$ & $\mathfrak{e}$ & & $\square$ & & & 0 \\
\hline & Perspective taking & & $\Delta$ & & & & & $\square$ & & & & \\
\hline & Being self-efficient & & & $\square$ & & & & $\square$ & & ஓ & & \\
\hline & $\begin{array}{l}\text { Being self- } \\
\text { conscious }\end{array}$ & & & & - & ○ & & & $\square$ & & $\mathrm{G}$ & ○ \\
\hline & $\begin{array}{l}\text { Developing self- } \\
\text { respect }\end{array}$ & & & & & & & $\square$ & $\square$ & ஓ & $\mathrm{G}$ & \\
\hline & $\begin{array}{l}\text { Developing } \\
\text { empathy }\end{array}$ & & & & & & & & $\square$ & & & \\
\hline \multirow{3}{*}{$\begin{array}{l}\text { Lifelong } \\
\text { learning } \\
\text { experience }\end{array}$} & Transferring & & $\Delta$ & $\square$ & $\cdot$ & o & & & & ळ & & \\
\hline & $\begin{array}{l}\text { knowledge to } \\
\text { professional life }\end{array}$ & & & & & & & & & & & \\
\hline & $\begin{array}{l}\text { Gaining life } \\
\text { experience }\end{array}$ & & & & & & & & & & $\mathrm{GO}$ & \\
\hline
\end{tabular}

Abbreviations for Performance Tasks: IFM: Interviewing family members; IIS: Interviewing individuals with SEN; BD: Blog design; PD: Performing drama; FA: Film analysis; PSD: Photographing living spaces with disabilities, OfI: Observation; DC: Designing a campaign; D: Debating; IT: Interviewing teachers; SI: Street interviews.

Lifelong learning experience. Taking part in certain of the performances, particularly conducting interviews, designing blogs, performing drama, conducting film analysis and debating, changed the view of student teachers on transferring what they had learned to their personal and professional lives in the future.

"Seeing the difficulties experienced by students with SEN made me aware of fact that though there are countless things that we can do for the disabled, we just do nothing. So from now on, I'll be trying to be more careful and considerate".

This statement, provided by a participant taking part in a drama performance, can be interpreted as to how authentic tasks have changed her vision of the future.

As a result, Table 5 summarizes the categories and themes in the axial theme.

Table 5

Categories and themes observed in the axial theme, 'Developing and understanding of persons with SEN'

\begin{tabular}{|c|c|c|c|c|c|c|c|c|c|c|c|c|}
\hline Themes & Categories & IFM & IIS & $B D$ & $P D$ & $F A$ & $P S D$ & OfI & $C D$ & $D$ & $I T$ & SI \\
\hline \multirow{7}{*}{$\begin{array}{l}\text { Developing and } \\
\text { understanding } \\
\text { of persons with } \\
\text { SEN }\end{array}$} & $\begin{array}{l}\text { Responsibility for } \\
\text { them }\end{array}$ & $\diamond$ & $\Delta$ & & & & & $\square$ & $\square$ & & $\omega$ & \\
\hline & $\begin{array}{l}\text { Sensibility for } \\
\text { them }\end{array}$ & $\diamond$ & & & & & & $\square$ & & 。 & $\omega$ & \\
\hline & Valuing them & $\diamond$ & & & $\cdot$ & ○ & & & & & $\omega$ & \\
\hline & $\begin{array}{l}\text { Being conscious of } \\
\text { them }\end{array}$ & $\diamond$ & & & & & & & & & $\omega$ & \\
\hline & Understanding & $\diamond$ & $\Delta$ & & & & & $\square$ & $\square$ & & $\omega$ & \\
\hline & Empathy for them & $\diamond$ & $\Delta$ & & & & & & & ळ & $\omega$ & \\
\hline & Recognizing them & $\diamond$ & $\Delta$ & $\square$ & & ○ & $\mathfrak{e}$ & & & . & $\omega$ & \\
\hline
\end{tabular}


Developing an understanding of persons with SEN. Developing an understanding of persons with SEN, learning their main characteristics, developing sensitivity and awareness of SEN and of persons with SEN, valuing and empathizing persons with SEN and developing a sense of responsibility towards these issues are the categories within this theme. Various performances the student teachers took part in had impact on the development of these feelings, understanding and skills. The following words expressed by a participant taking part in the debating task reveal the improvements in the participants' vision and awareness.

"I think I understood how difficult the lives of visually impaired persons are. I've seen how other people underestimate or ignore them and make their lives even worse. Thus, this research process has enabled us to become more sensitive about the visually impaired."

In addition, by saying, "Our understanding of students with emotional and behavioral disorders improved our empathy and sympathy of special students, and this helped us to learn how to approach them", another student teacher indicates the feelings and skills they have gained within the course of the current study.

The categories and themes under the interaction inclusive theme are summarized in Table 6.

Table 6

Categories and themes observed under inclusive theme 'Interaction'

\begin{tabular}{|c|c|c|c|c|c|c|c|c|c|c|c|c|}
\hline Themes & Categories & IFM & $I I S$ & $B D$ & $P D$ & $F A$ & $P S D$ & OfI & $C D$ & $D$ & $I T$ & SI \\
\hline \multirow{6}{*}{$\begin{array}{l}\text { Interacting with } \\
\text { family members } \\
\text { of persons with } \\
\text { SEN }\end{array}$} & $\begin{array}{l}\text { Family boredom } \\
\text { with questions }\end{array}$ & $\diamond$ & & & & & & & & & & \\
\hline & $\begin{array}{l}\text { Family } \\
\text { acceptance of this } \\
\text { situation }\end{array}$ & $\diamond$ & $\Delta$ & & & & & & & & & \\
\hline & $\begin{array}{l}\text { Understanding } \\
\text { family life }\end{array}$ & $\diamond$ & $\Delta$ & & & & & & & & & \\
\hline & Intimate dialogue & & & & & & & $\square$ & & & & \\
\hline & with the family & & & & & & & & & & & \\
\hline & $\begin{array}{l}\text { Witnessing the } \\
\text { competence and } \\
\text { effort of } \\
\text { individuals with } \\
\text { SEN }\end{array}$ & & & & & & & $\square$ & & & & \\
\hline \multirow{5}{*}{$\begin{array}{l}\text { Observing } \\
\text { teachers and } \\
\text { taking them as } \\
\text { role models }\end{array}$} & $\begin{array}{l}\text { Witnessing the } \\
\text { teacher } \\
\text { experience }\end{array}$ & & & & & & & & & & $\mathrm{G}$ & \\
\hline & $\begin{array}{l}\text { Taking a role } \\
\text { model }\end{array}$ & & & & & & & & & & $\mathrm{G}$ & \\
\hline & $\begin{array}{l}\text { Positive } \\
\text { authority } \\
\text { behavior }\end{array}$ & & & & & & & & & & $\mathrm{G}$ & \\
\hline & $\begin{array}{l}\text { Learning teacher } \\
\text { strategies }\end{array}$ & & & & & & & & & & $\mathrm{G}$ & \\
\hline & $\begin{array}{l}\text { Affected by } \\
\text { authority }\end{array}$ & & & & & & & $\square$ & & & & \\
\hline \multirow{3}{*}{ Emotional ties } & $\begin{array}{l}\text { Recognizing } \\
\text { emotional } \\
\text { bonding }\end{array}$ & $\diamond$ & $\Delta$ & & & & & $\square$ & $\square$ & \% & $\mathrm{G}$ & \\
\hline & Positive emotion & $\diamond$ & & & & ○ & & & & & & \\
\hline & $\begin{array}{l}\text { Negative } \\
\text { emotion }\end{array}$ & $\diamond$ & $\Delta$ & $\square$ & & ० & $\mathfrak{e}$ & & & ळ & & \\
\hline
\end{tabular}

Abbreviations for Performance Tasks: IFM: Interviewing family members; IIS: Interviewing individuals with SEN; BD: Blog design; PD: Performing drama; FA: Film analysis; PSD: Photographing living spaces with disabilities, OfI: Observation; DC: Designing a campaign; D: Debating; IT: Interviewing teachers; SI: Street interviews. 
Interacting with the family members of those with SEN. As Table 6 presents, the categories raised within this theme are becoming tired of uninteresting and awkward questions, acknowledging and accepting the situation, developing an understanding of the lives of families with a person with SEN, having open and sincere dialogues with family members and witnessing the competence and effort of individuals with SEN. One of the participants, who was involved in the task of interviewing the family members of those with SEN raises issues related to first category given above in these words:

"These interviews helped me to overcome my anxious attitudes and my inability to communicate with others that I've never met before. I had a chance to see the way in which these families think and how they struggle to cope with such a difficult life."

The findings also indicate that observing parents and families who indulgently accept their child's situation was a different, interesting and exciting experience for the participants. One student teacher put this experience in the following words:

"It was really fascinating to see that despite the problems and difficulties they have been facing in everyday life, these families regard their handicapped children as gifts send to them by the God. We observed that they had already acknowledged and accepted this and were ready to do whatever they could for their spouse with SEN."

Observing teachers and taking them as role models. As can be seen in Table 6, witnessing special education teachers' teaching performances and conditions, considering teachers as role models, witnessing the positive behavior of powerful people, being influenced by these powerful people and learning relevant teaching strategies are the categories aroused within this theme.

Emotional ties. The research participants' interaction with individuals with SEN and other people sharing/contributing to their lives enabled them to set up emotional connection with these people. One student teacher stating, "... as I observed the life of the person I contacted, I got some feelings of sadness and sadness. However, this assignment has contributed a lot to me", indicated the point that their communication and interaction with persons with SEN touched their feelings and made them emotionally bonded with those individuals.

The categories and themes under the critics inclusive theme are summarized in Table 7.

Table 7

Categories and themes observed under inclusive theme 'Critics'

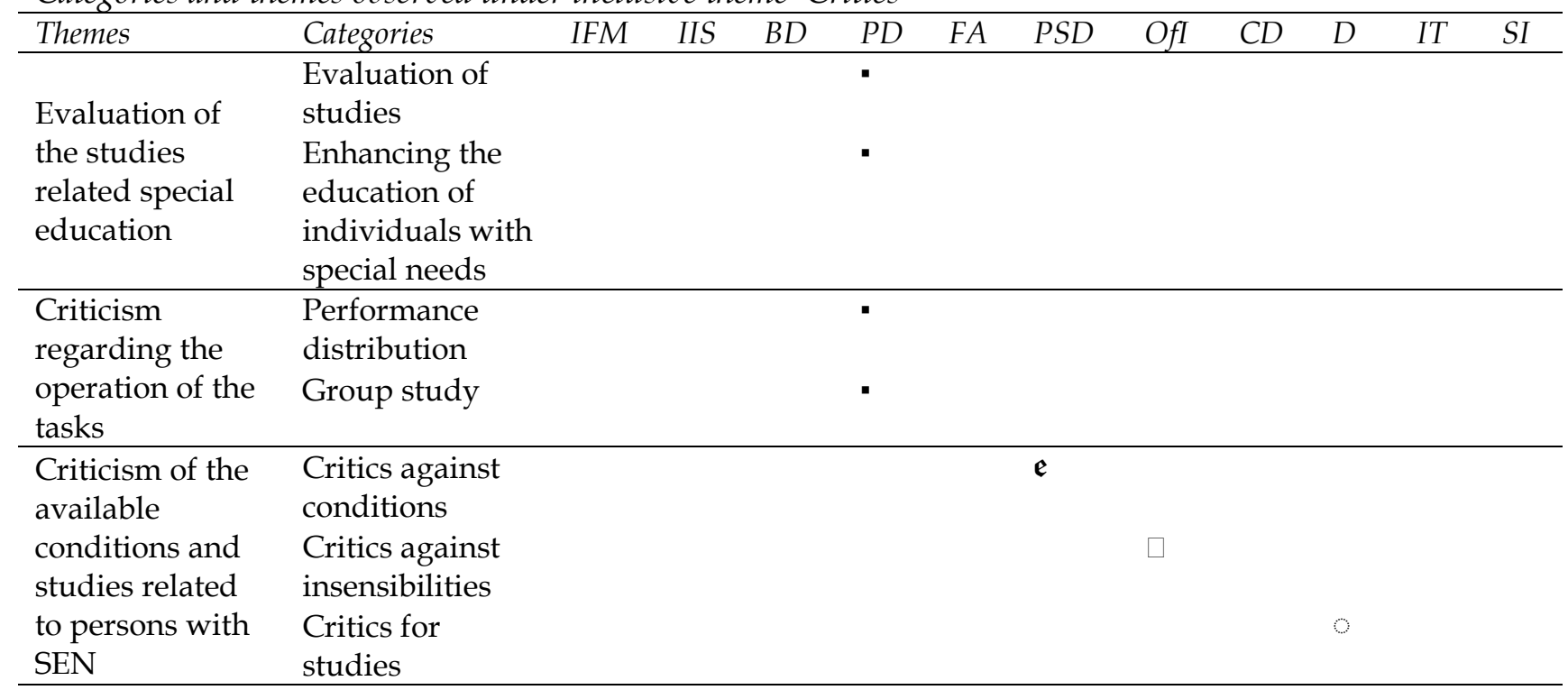

Abbreviations for Performance Tasks: IFM: Interviewing family members; IIS: Interviewing individuals with SEN; BD: Blog design; PD: Performing drama; FA: Film analysis; PSD: Photographing living spaces with disabilities, OfI: Observation; DC: Designing a campaign; D: Debating; IT: Interviewing teachers; SI: Street interviews. 
Evaluation of studies related to special education. Another theme revealed is the evaluation of the studies in and related to special education, along with the theme of educating individuals with SEN. In particular, the opinion of a participant involved in a drama performance regarding the evaluation and development of special education studies is as follows:

"Taking place in this task made me realize that studies on multiple disabilities have arrived at a better stage in recent years, but they still have several shortcomings. The public should be informed more about this issue. I also noticed that there are not many studies dealing with this issue, especially in a school context. So, I believe that the number of educators in this field should be increased along with the number of people doing this job with love."

Critics regarding the operation of the tasks. The available data reveals that the student teachers performing the drama in particular criticized the distribution of tasks and roles among the group members, because they thought that carrying out certain tasks or performing certain roles were not suitable for their personalities. Some participants also stated that working in a group was not suitable for them. A male student teacher explained, "Working as a group in this performance forced me too much. Otherwise, our task was perfect, sir". The issues raised within this theme indicate the problems or shortcomings of the research design that should be taken into consideration in further studies.

Critics of the available conditions and studies related to persons with SEN. Within the framework of this theme, a student teacher performing photography tasks, criticized the insufficiency of the facilities and/or opportunities available for disabled individuals saying, "In this process, I had chances to observe the facilities and places made ready for the use of the visually impaired. I've seen countless deficiencies and inadequate facilities out there". A number of participants also raised the issues that many people are not aware of the conditions limiting or negatively influencing the lives of disabled, and the limited number and quality of studies dealing with disability, the life conditions of disabled people and the educational opportunities available for persons with SEN.

Table 8 shows the categories and themes under the satisfaction inclusive theme.

Table 8

Categories and themes observed under inclusive theme 'Satisfaction'

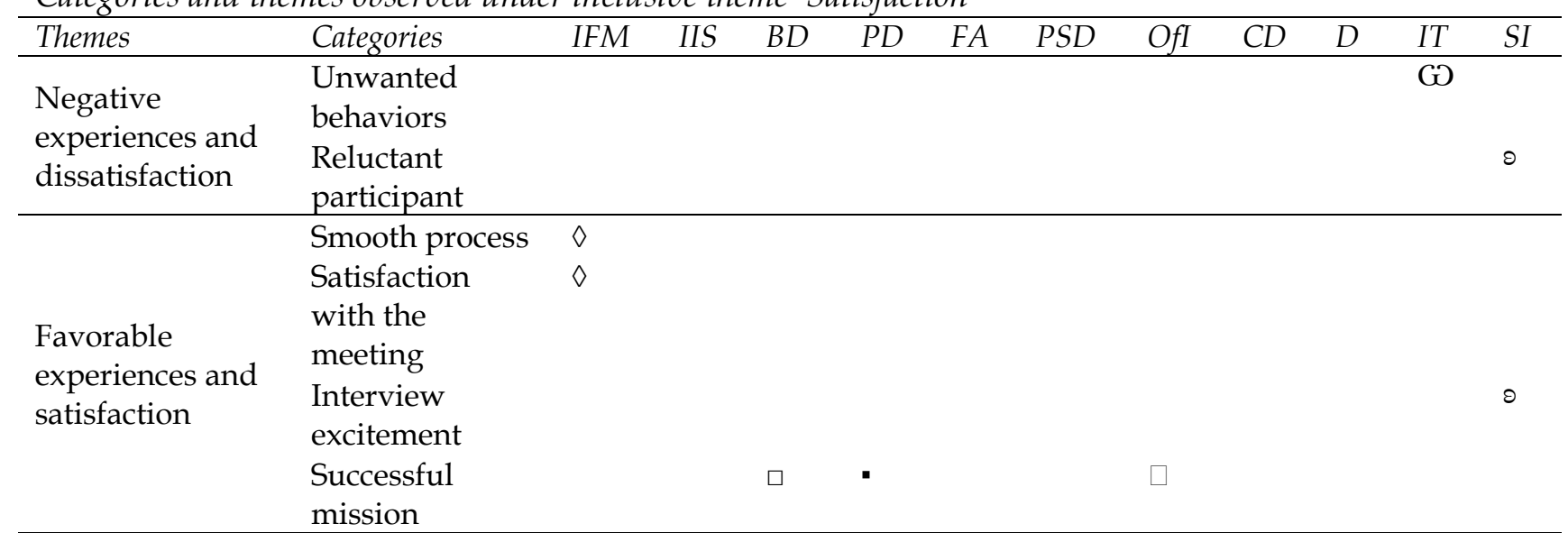

Abbreviations for Performance Tasks: IFM: Interviewing family members; IIS: Interviewing individuals with SEN; BD: Blog design; PD: Performing drama; FA: Film analysis; PSD: Photographing living spaces with disabilities, OfI: Observation; DC: Designing a campaign; D: Debating; IT: Interviewing teachers; SI: Street interviews.

Negative experiences and dissatisfaction. Contrary to the previous theme, a number of participants pointed out that while trying to conduct interviews, some of their interviewees were not willing to talk in detail or some decided to withdraw after the commencement of the interviews. Explaining this issue, one student teacher stated:

"One of my interviewees gave up when she realized that she would be filmed. My children may get angry, she said. An older man even avoided expressing his opinion by saying, "I don't know, and it is not possible to talk about an issue I don't know about", even before finishing my sentence." 
Aiming to interview a special education teacher in her school, another group of participants experienced a different problem. A member of this group stated, "In the rehabilitation center, we met a manager constantly trying to reveal our soft spot. So, this made us uneasy and thus that task turned into a messy thing." This evidence shows that the success of the authentic performance task not only requires the enthusiasm, willingness and effective participation of the learners, but also necessitates a positive working environment and culture available for them.

Favorable experiences and satisfaction. The available data collected through diaries presents that most participants, particularly those taking parts in interviewing tasks, had exciting, informed and satisfying experiences. Here is one example:

"Before the interviews, we were being afraid of unintentionally or unconsciously hurting the other side? We're worried about the probability of our potential interviewees not agreeing to talk to us, or not being willing to tell us about their actual experiences, thoughts and feelings. Later on, we realized that they were actually ready and willing to talk to us. This experience made me realize that there are many things we can do for our society, even by talking to persons with SEN and others sharing their lives."

The above extract, going through authentic learning processes, not only overcame their initial fears or worries, but also had fruitful learning experiences which raised their awareness.

The codes and themes under the quality of the performance tasks inclusive theme are summarized in Table 9.

Table 9

Categories observed under the theme 'Quality of the performance tasks'

\begin{tabular}{|c|c|c|c|c|c|c|c|c|c|c|c|c|}
\hline Themes & Categories & IFM & IIS & $B D$ & $P D$ & $F A$ & $P S D$ & OfI & $C D$ & $D$ & $I T$ & SI \\
\hline \multirow{6}{*}{$\begin{array}{l}\text { The quality of } \\
\text { performance }\end{array}$} & Educative & $\diamond$ & & & & o & & & $\square$ & o & & 0 \\
\hline & Enjoyable & $\diamond$ & $\Delta$ & $\square$ & . & o & & & $\square$ & o & $\omega$ & 0 \\
\hline & Compelling & $\diamond$ & $\Delta$ & $\square$ & & & & & $\square$ & & & 0 \\
\hline & Innovative & & & $\square$ & & & & & & o & & \\
\hline & Motivating & & & & - & & & & & & & \\
\hline & Easy to do & & & & & & $\mathfrak{e}$ & $\square$ & & & & \\
\hline
\end{tabular}

Abbreviations for Performance Tasks: IFM: Interviewing family members; IIS: Interviewing individuals with SEN; BD: Blog design; PD: Performing drama; FA: Film analysis; PSD: Photographing living spaces with disabilities, OfI: Observation; DC: Designing a campaign; D: Debating; IT: Interviewing teachers; SI: Street interviews.

The quality of the performance tasks. This theme indicates that the participants found the tasks to be enjoyable, educational, innovative, challenging, motivating and easy. In particular, those being involved in interviews, film analysis, campaign design and debating stated that these performances were educative, enjoyable and innovative, as one of them expresses: "I saw myself as a high school student until I got this task. There was no activity in our classes. This performance gave me the opportunity to meet disabled students, and it was a social activity". Although, the findings presented under certain of the previous themes show the problems, difficulties and dissatisfaction that the participants experienced, this extract reveals that many of them were happy to be involved in the performance activities carried out within the context of the current study, because these activities made them actively involved in learning processes and being sociable.

\section{Discussion and Conlusion}

In this study, the experiences and viewpoints of the student teachers on the authentic performance tasks, designed and implemented within the scope of a special education course, are examined. These experiences and reflections are discussed through comparing and contrasting eleven performance tasks. The analysis of the available data produced seventeen themes: (a) Context: Presuppositions and pre-skills; (b) research and scientific process skills; (c) methodological knowledge and skills; (d) effective communication and self-confidence; (e) visual skills and manual skills; (f) self-efficacy; $(\mathrm{g})$ lifelong learning experience; $(\mathrm{h})$ developing understanding towards the individual with special needs; (i) interaction with the family; (j) evaluation of special education; (k) criticism 
of performances; (l) criticism about current conditions and studies; (m) satisfaction from the performances; (n) observing and taking teachers as role models; (o) dissatisfaction with performances; $(\mathrm{p})$ establishing an emotional connection in the interaction process; and (r) the quality of performance.

The implementation of performance tasks requiring them to interact with students with special needs reveals that before the execution of the current study, student teachers lacked necessary knowledge/information, awareness, experience and skills related to science process skills and individuals with special needs. Related studies (Lebow \& Wager, 1994; Jobling \& Moni, 2004) underline that the above-mentioned problems may stem from the fact that special education courses taught at undergraduate level are mostly-based on rote learning and memorization of abstract information devoid of context, and do not include any practical application. Within the course of the current study, it can be seen that the capacities of student teachers related to understanding the lives of individuals with special needs, empathizing with them, gaining sensitivity and awareness of facilitating their lives and taking over responsibility, have improved to a certain degree. It can be concluded that special needs education requires high level training, commitment and collaboration (Belay, 2020). Overlapping with the results of the studies carried out by Best et al. (2017) and Doody (2018) on authentic learning, the performance tasks enabled student teachers to gain in-depth knowledge, skills and attitudes.

As a result of another finding of the current study, underlining the acquisition of knowledge, awareness, skills and experience related to the lives of the individuals with SEN, the participating student teachers felt ready, competent and able to utilize these in their future professional lives and to deal with potential problems. In a study (Nguyen, 2017) based on the use of three authentic assessment tasks within a pedagogy-based module in an undergraduate course, student teachers saw an association between the contents, criteria, social contexts of these tasks and the duties of teachers working actively in schools. Nguyen's (2017) study also points out that participating in these tasks affects student teachers' learning strategy, motivation, professional competency and professional identity. Furthermore, a collaborative initiative between Autism Spectrum Australia and the University of Western Sydney arranged for students with SEN and student teachers come together through a social network to interact safely. It was found that student teachers developed a comprehensive understanding of people with autism spectrum disorder in an authentic environment, which could be transferred to other teaching contexts (Power \& Costley, 2014). Bain and Hasio (2011) also found that, in such experiences, student teachers learned how to work with different groups of learners, be flexible, be patient, and how to differentiate teaching for students with different learning levels and paces. It can be asserted that the results of the current paper correspond with the findings of the above given studies in many respects.

One of the results of this study is that student teachers personally witness the living conditions and struggles of families of children with SEN, and develop sensitivity, awareness and empathy towards these families. Similar results were obtained in studies by Collier et al. (2015), and it was pointed out how the lives of parents were particularly affected. As a result of their authentic learning experiences, student teachers' empathizing with individuals with SEN realized the value of their own health. This can be considered to be a common finding of the current study and the research by Collier et al. (2015). The results of the study also show that there are worthwhile improvements in student teachers' self-efficacy, self-confidence and perspectives and lifelong learning experiences. Emphasizing on the change in the perceptions of student teachers after family visits and listening to family stories, these findings overlap with the results of the study by Collier et al. (2015). Both studies point out that such performances lead to significant change and improvement in the professional development of student teachers and their viewpoints.

Throughout the current study, student teachers developed research and science process skills, including authentic learning, planning and decision-making, observation, inquiry and analysis, problem-solving and interpretation. In addition, they acquired and improved their skills of collaborating, conducting interviews and blogging, and learned sign language. Chase et al. (2017) 
also conclude in their studies that courses based on research experience improve participants' data collection, analytical skills as well as scientific thinking and critical thinking skills. Moore (2012) and Mordacq et al. (2017) point out that similar processes enable student teachers to develop their scientific inquiry skills by thinking like scientists. It can be said that the mentioned studies and the results of this study significantly overlap.

The results obtained from several studies (Haston \& Russell, 2012; Russell-Bowie, 2012; MrazCraig et al. 2018; Rebull et al. 2018), based on authentic learning experiences, demonstrate the increase of the participants' self-confidence, in addition to improvements in their motivation, the development of their professional identities and the opportunity to associate these identities with their future career plans, along with the development of their communication skills and personal satisfaction (Buck, 2003; Castillo et al., 2017). The above given findings coincide with the results of the current study, related to the issues of self-efficacy, self-awareness, imagination, empathy and so on.

\section{Recommendations}

This study focuses on an authentic performance-based learning experience in teacher training within the context of a special education course. Professional development can be reshaped by understanding authentic learning in teacher training (Webster-Wright, 2009). However, student teachers need to perform more professional practices to ensure authenticity in learning and teaching (Rowland et al. 2016). This is possible if teacher educators design their lessons in a format largely based on research experience. In this way, they can turn their lessons into authentic learning activities (Chase et al., 2017). Within this context, it is advised that teachers or student teachers should design authentic tasks (Robertson, 2016) and problem-based learning activities covering real life situations (Barron \& Wells, 2013). In particular, with special education, it is recommended to develop instructional designs in which problem-based learning, place-based learning and situational learning approaches may also be used within the framework of the Understanding by Design Model. In addition to the performance tasks employed as an authentic assessment activity used in the current study, the following tasks/activities may be used for the same purpose: taking short films to raise public awareness on individuals with SEN; designing and applying social experiments to stimulate people's awareness on such issues; and establishing workshops and social club activities related to the lives and training of individuals with SEN.

Acknowledgements. The current study was presented orally at the International Pegem Conference on Education (IPCEDU), held in September 16-19, 2020.

\section{References}

Aksoy, A., Çavuşoğlu, T. \& Kalayci, G. Ö. (2018). A qualitative examination of the serviceability of teaching practice modifications aimed for special education teacher candidates. Journal of Special Education Apprenticeship, 7(2), 1-16.

Alexakos, K. (2015). Being a teacher-researcher: A Primer on doing authentic inquiry research on teaching and learning. Sense Publishers.

Bain, C., \& Hasio, C. (2011). Authentic learning experience prepares preservice students to teach art to children with special needs. Art Education, 64(2), 33-39. https://doi.org/10.1080/00043125.2011.11519118

Banas, J. R. (2014). Impact of authentic learning exercises on preservice teachers' self-efficacy to perform bullying prevention tasks. American Journal of Health Education, 45(4), 239-248. https:/ / doi.org/10.1080/19325037.2014.916634

Banas, J. R., \& York, C. S. (2014a). Authentic learning exercises as a means to influence preservice teachers' technology integration self-efficacy and intentions to integrate technology. Australasian Journal of Educational Technology, 30(6), 728-746. https://doi.org/10.14742/ajet.362

Banas, J. R., \& York, C. S. (2014b). The impact of authentic learning exercises on pre-service teachers' motivational beliefs toward technology integration. International Journal of Information and Communication Technology Education, 10(3), 60-76. https:/ / doi.org/10.4018/ijicte.2014070105 
Barron, L. \& Wells, L. (2013). Transitioning to the real world through problem-based learning: A collaborative approach to teacher preparation. Journal of Learning in Higher Education, 9(2), 13-18.

Belay, M. A. (2020). Educating special children: An introduction to provision for pupils with disabilities and disorders [Book review]. International Journal of Didactical Studies, 1(1), 43-48

Best, M., MacGregor, D., \& Price, D. (2017). Designing for diverse learning: Case study of place-based learning in design and technologies pre-service teacher education. Australian Journal of Teacher Education, 42(3), 91-106. http:// doi.org/10.14221/ajte.2017v42n3.6

Bhagat K. K., Huang R. (2018). Improving learners' experiences through authentic learning in a technologyrich classroom. In T. W. Chang, R. Huang, Kinshuk (Eds.), Authentic Learning Through Advances in Technologies. Lecture Notes in Educational Technology (pp.3-15). Springer.

Bozgeyikli, H. (2018). Psychological needs as the working-life quality predictor of special education teachers. Universal Journal of Educational Research, 6(2), 289-295. https:/ / doi.org/10.13189/ujer.2018.060211

Buck, P. E. (2003). Authentic research experiences for Nevada high school teachers and students. Journal of Geoscience Education, 51(1), 48-53. https:/ / doi.org/10.5408/1089-9995-51.1.48

Bruffy, W. R. (2012). Authentic tasks: A participatory action research study on a teaching method for the inclusive classroom [Unpublished doctoral dissertation]. Northeastern University.

Carr, W., \& Kemmis, S. (2002). Becoming critical: Education, knowledge and action research. Falmer.

Castillo, C. A., Insuasty, E. A. \& Jaime Osorio, M. F. (2017). The impact of authentic materials and tasks on students' communicative competence at a Colombian language school. PROFILE: Issues in Teachers' Professional Development, 19(1), 89-104. https:// doi.org/10.15446/profile.v19n1.56763

Chase, A. M., Clancy, H. A., Lachance, R. P., Mathison, B. M., Chiu, M. M. \& Weaver, G. C. (2017). Improving critical thinking "via" Authenticity: The CASPiE research experience in a Military Academy Chemistry Course. Chemistry Education Research and Practice, 18(1), 55-63.

Collier, m., Keefe, E. B. \& Hirrel, L. A. (2015). Listening to parents' narratives: the value of authentic experiences with children with disabilities and their families. School Community Journal, 25(2), 221-242.

Dennis, L. R., Rueter, J. A. \& Simpson, C. G. (2013) Authentic assessment: Establishing a clear foundation for instructional practices. Preventing School Failure: Alternative Education for Children and Youth, 57(4), 189-195. https:/ / doi.org/10.1080/1045988X.2012.681715

Dewer, R. \& Clement, S. (2016). Middle school pre-service teachers' sense of self-efficacy in relation to authentic learning experiences. Electronic Journal of Science Education, 20(5), 39-52.

Doody, K. R. (2018). Training pre-service and in-service teachers to work with students with ASD: au-some experiences in community-based learning. International Journal of Research in Education and Psychology (IJREP), 4(1), 1-17.

Haston, W. \& Russell, J. A. (2012). Turning into teachers: Influences of authentic context learning experiences on occupational identity development of preservice music teachers. Journal of Research in Music Education, 59(4), 369-392. https://doi.org/10.1177/0022429411414716

Herrington, A., \& Herrington, J. (2006). Authentic learning environments in higher education. Information Science Publishing.

Herrington, J., Reeves, T. C. \& Oliver, R. (2010). A guide to authentic e-learning. Routledge.

Hursen, C. (2016). The impact of curriculum developed in line with authentic learning on the teacher candidates' success, attitude and self-directed learning skills. Asia Pacific Education Review, 17(1), 73-78. https:// doi.org/10.1007/s12564-015-9409-2

Jobling, A., \& Moni, K. B. (2004). 'I never imagined I'd have to teach these children': Providing authentic learning experiences for secondary pre-service teachers in teaching students with special needs. AsiaPacific Journal of Teacher Education, 32(1), 5-22. https:/ / doi.org/10.1080/1359866042000206026

Kocyigit, S. \& Zembat, R. (2013). The effects of authentic tasks on preservice teachers' attitudes towards classes and problem solving skills. Educational Sciences: Theory \& Practice, 13(2), 1045-1051.

Laiken, M. (2006). Authentic graduate education for personal and workplace transformation A. Herrington \& J. Herrington (Eds.), Authentic learning environments in higher education (pp.15-33). IGI-Global.

Laur, D. (2013). Authentic learning experiences: A real-world approach to project-based learning. Routledge.

Lebow, D.G., \& Wager, W. (1994). Authentic activity as a model for appropriate learning activity: Implications for emerging instructional technologies. Canadian Journal of Educational Communication, 23(3), 231-244.

Lowell, V. L., \& Moore, R. L. (2020). Developing practical knowledge and skills of online instructional design students through authentic learning and real-world activities. TechTrends, 64(4), 581-590. https:/ / doi.org/10.1007/s11528-020-00518-z 
McCall, Z., McHatton, P. A. \& Shealey, M. W. (2014). Special education teacher candidate assessment: A review. Teacher Education and Special Education, 37(1), 51-70. https:/ / doi.org/10.1177/0888406413512684

Ministry of National Education [MoNE]. (2020). Ulusal eğitim istatistikleri: Formal eğitim [National education statistics: Formal education]. http://sgb.meb.gov.tr/meb_iys_dosyalar/2020_09/04144812_meb_istatistikleri_orgun_egitim_2019_202 $0 . p d f$

Mohammadi, F. S. (2017). The effect of authentic problem-based vocabulary tasks on vocabulary learning of EFL learners. International Journal of Education and Literacy Studies, 5(3), 35-40.

Moore, J. C. (2012). Transitional to formal operational: Using authentic research experiences to get nonscience students to think more like scientists. European Journal of Physics Education, 3(4), 1-12.

Mordacq, J. C., Drane, D. L., Swarat, S. L. \& Lo, S. M. (2017). Research and teaching: Development of coursebased undergraduate research experiences using a Design-Based Approach. Journal of College Science Teaching, 46(4), 64-75.

Mraz-Craig, J. A., Daniel, K. L., Bucklin, C. J., Mishra, C., Ali, L. \& Clase, K. L. (2018). Student identities in authentic course-based undergraduate research experience. Journal of College Science Teaching, 48(1), 69-75.

Nguyen, T. T. H. (2017). Authentic assessment in pedagogy-related modules in teacher education: Vietnamese student teachers' perspective [Unpublished doctoral dissertation]. University of East Anglia.

Önger, S. \& Çetin, T. (2018). An investigation into digital literacy views of social studies preservice teachers in the context of authentic learning. Review of International Geographical Education Online (RIGEO), 8(1), 109-124.

Pierrakos, O., Zilberberg, A. \& Anderson, R. (2010). Understanding undergraduate research experiences through the lens of problem-based learning: Implications for curriculum translation. Interdisciplinary Journal of Problem-based Learning, 4(2), 35-62. https:// doi.org/10.7771/1541-5015.1103

Power, A. \& Costley, D. (2014). Preservice teachers' learning among students with autism spectrum disorder. Australasian Journal of Special Education, 38(1), 34-50.

Rebull, L. M., Roberts, T., Laurence, W., Fitzgerald, M. T., French, D. A., Gorjian, V. \& Squires, G. K. (2018). Motivations of educators for participating in an authentic astronomy research experience professional development program. Physical Review Physics Education Research, 14(1), 010148. https://doi.org/10.1103/PhysRevPhysEducRes.14.010148

Robertson, K. (2016). An authentic research experience for undergraduates on a budget: Using data from simple experiments to develop mini-research proposals. Journal of College Science Teaching, 46(2), 32-36.

Rowland, S., Pedwell, R., Lawrie, G., Lovie-Toon, J. \& Hung, Yu. (2016). Do we need to design course-based undergraduate research experiences for authenticity? CBE - Life Sciences Education, 15(4), 1-16. https://doi.org/10.1187/cbe.16-02-0102

Russell-Bowie, D. E. (2012). Developing preservice primary teachers' confidence and competence in arts education using principles of authentic learning. Australian Journal of Teacher Education, 37(1) 60-74.

Webster-Wright, A. (2009). Reframing professional development through understanding authentic

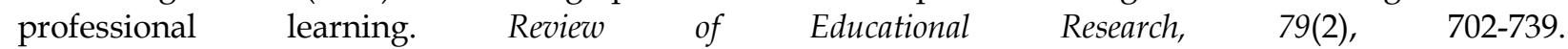
https://doi.org/10.3102/0034654308330970

Wiggins, G., \& McTighe, J. (1998). Understanding by Design. ASCD.

Wiggins, G., \& McTighe, J. (2011). The Understanding by Design guide to creating high-quality units. ASCD.

Wiggins, G. ve McTighe, J. (2012). The Understanding by Design guide to advanced concepts in creating and reviewing units. ASCD.

Zagrodnik, J., Williams, N. A., \& Leytham P. A. (2017). Pre-service educator preparation to teach children with disabilities through service-learning. International Journal of Research on Service-Learning and Community Engagement, 5(1), 161-180. 


\section{Appendix 1. Final version of street interview schedule}

1. Please read the text below. Who could have written this?

"Bunu kokuren kılmatanızın nedien kezanız derildiği saeecd raflehrin karlıf alsıgılanma eli gilidir."

(If the respondent provides the right answer, ask her/him about it.)

What does she/he know about the concept of 'dyslexia'?

(Then move on to the third and fourth questions.)

(If the respondent cannot provide the right answer for the initial question, then continue with the second question)

2. Have you ever heard the word dyslexia?

(If the respondent gives a negative response ask her/him.)

Have you seen or heard about the movie, 'Like Stars on Earth'?

(If she/he says that she/he has seen the movie, invite and let she/he talk about the story. Then make clear what dyslexia means, and explain it as well as you can before moving on to the third and fourth questions.)

3. Do you know anyone with dyslexia?

4. If you had a child with dyslexia, how would you feel, and what would you think? Please tell us as much as you can. 